\title{
Synergistic effect of the sequential use of UV irradiation and chlorine to disinfect reclaimed water
}

\author{
Xiujuan Wang, Xuexiang $\mathrm{Hu}$, Haibo Wang, Chun $\mathrm{Hu}^{*}$ \\ State Key Laboratory of Environmental Aquatic Chemistry, Research Center for Eco-Environmental Sciences, Chinese Academy of Sciences, \\ Beijing 100085, China
}

\section{A R T I C L E I N F O}

Article history:

Received 8 June 2011

Received in revised form

7 December 2011

Accepted 10 December 2011

Available online 22 December 2011

\section{Keywords:}

Chlorine disinfection

Disinfection by product

Photoreactivation

Sequential disinfection

UV disinfection

Wastewater reclamation

\begin{abstract}
A B S T R A C T
The effectiveness of UV and chlorination, used individually and sequentially, was investigated in killing pathogenic microorganisms and inhibiting the formation of disinfection by-products in two different municipal wastewaters for the source water of reclaimed water, which were from a microfilter (W1) and membrane bioreactor (W2) respectively. Heterotrophic plate count (HPC), total bacteria count (TBC), and total coliform (TC) were selected to evaluate the efficiency of different disinfection processes. UV inactivation of the three bacteria followed first-order kinetics in W1 wastewater, but in W2 wastewater, the UV dose-response curve trailed beyond approximately $10 \mathrm{~mJ} / \mathrm{cm}^{2} \mathrm{UV}$. The higher number of particles in the W2 might have protected the bacteria against UV damage, as UV light alone was not effective in killing HPC in W2 wastewater with higher turbidity. However, chlorine was more effective in $\mathrm{W} 2$ than in $\mathrm{W} 1$ for the three bacteria inactivation owing to the greater formation of inorganic and organic chloramines in W1 wastewater. Complete inactivation of HPC in W1 wastewater required a chlorine dose higher than $5.5 \mathrm{mg} / \mathrm{L}$, whereas $4.5 \mathrm{mg} / \mathrm{L}$ chlorine gave the equivalent result in W2 wastewater. In contrast, sequential UV and chlorine treatment produced a synergistic effect in both wastewater systems and was the most effective option for complete removal of all three bacteria. UV disinfection lowered the required chlorine dose in W1, but not in W2, because of the higher chlorine consumption in W2 wastewater. However, UV irradiation decreased total trihalomethane formation during chlorination in both wastewaters.
\end{abstract}

(c) 2011 Elsevier Ltd. All rights reserved.

\section{Introduction}

Reclaimed water as an alternative water source for domestic, industrial, agricultural, and recreational purposes is providing an increasing contribution to sustainable water resources in many areas of the world. To minimize the public risks associated with exposure to reclaimed water, an adequate disinfection process is necessary. Traditionally, chlorination has been the most commonly adopted disinfection process for the treatment of both drinking and reclaimed water. However, with the appearance of Cryptosporidium paruum oocysts and Giardia lamblia cysts, which are chlorine-resistant pathogenic microorganisms, free chlorine can seldom achieve the required target goals for microbial inactivation (Korich et al., 1990; Mackenzie et al., 1994). Additionally, chlorine disinfection results in numerous byproducts such as haloacetic acids and trihalomethanes, which exhibit potentially carcinogenic activity (Adin et al., 1991; Fawell et al., 1997). Achieving an appropriate balance between disinfection and disinfection by-products (DBPs) has

\footnotetext{
* Corresponding author. Tel: +8610 62849628; fax: +861062923541.

E-mail address: huchun@rcees.ac.cn (C. Hu).
} 
been the focus in extensive investigations of alternative disinfection processes.

Ultraviolet irradiation is a promising alternative to free chlorine as a primary disinfectant, because of its ability to inactivate C. parvum without producing DBPs at common disinfection doses (Liu et al., 2002; Liberti et al., 2003). However, owing to a lack of residual activity and the possible repair of UV-damaged microorganisms (Hassen et al., 2000; Oguma et al., 2004), UV irradiation cannot be used as a stand-alone disinfectant. Nevertheless, using UV light as a primary disinfectant could potentially lower effective chemical doses and provide further disinfecting capabilities. The combination of UV irradiation as a primary disinfectant and free chlorine or monochloramine as a secondary disinfectant has been shown not only to prevent subsequent microbial regrowth but also to produce a synergetic disinfection (Ballester and Malley, 2004; Shang et al., 2007). However, other studies have reported mixed results for the effect of UV irradiation on DBP formation and chemical disinfectant dosages. Some researchers have found that UV disinfection lowered the possibility of harmful DBP formation (Cotton et al., 2001), whereas others have reported that UV treatment neither lowered the required chemical dosages nor significantly affected DBP formation upon subsequent chemical disinfection (Rand et al., 2007). The quality of the water to be treated may have a great influence on the role of UV in combined disinfection. All of the studies cited above were conducted as drinking water treatments. To our knowledge, little studies of the combination of UV and secondary chemical disinfection in treating reclaimed water has been carried out to determine microbial inactivation and DBP formation (Montemayor et al., 2008).

We investigated the effectiveness of UV and chlorination, alone and together, in killing pathogenic microorganisms and inhibiting DBP formation in wastewater from two different wastewater reclamation plants. Heterotrophic plate count (HPC), total bacteria count (TBC), and total coliform (TC) in the wastewater were examined to evaluate the effectiveness of different disinfection processes.

\section{Materials and methods}

\subsection{Wastewater samples}

Wastewater samples were collected from points upstream of the disinfection process at two different wastewater reclamation plants in Tianjin, China. All samples were stored at $4{ }^{\circ} \mathrm{C}$ before analysis. The wastewater treatment processes before disinfection were prechlorination, coagulation, sedimentation, and microfiltration at the first plant (W1), and fine screening, aerated grit removal, primary clarification, and membrane bioreactor application at the second (W2).

\subsection{Water quality analysis}

Measurement of particle size distributions was carried out using a Mastersizer 2000 (Malvern, UK). One sample was repeated five times and background measurement time of $25 \mathrm{~s}$ and a refractive index of 1.52 . The minimum and maximum detection limits were $0.2 \mu \mathrm{m}$ and $2000 \mu \mathrm{m}$. Nitrate and nitrite were measured using the Dionex ICS-2000 ion chromatography system (Dionex Corp., CA), while $\mathrm{NH}_{3}-\mathrm{N}$ was analyzed by Nesslerization method (UV-vis spectrophotometer-U-3100, Hitachi Co., Japan). Dissolved organic carbon (DOC) and total dissolved nitrogen (TDN) were measured using a Shimadzu TOC- $\mathrm{V}_{\mathrm{CPH}}$ analyzer with a TNM-1 TN unit (Shimadzu, Japan). The amount of dissolved organic nitrogen (DON) was obtained by subtracting the concentration of inorganic nitrogen from the total dissolved nitrogen. In addition, total suspended solids (TSS), volatile suspended solids (VSS), $\mathrm{pH}$ and $\mathrm{UV}_{254 \mathrm{~nm}}$ were determined according to standard methods for the examination of water \& wastewater (APHA, 1998). The water quality parameters of both wastewaters were shown in Table 1.

\subsection{Enumeration of indicator bacteria}

In the experiment, heterotrophic plate count (HPC), total bacteria count (TBC), and total coliform (TC) in the wastewater were measured for evaluating the disinfection efficiency. TC was enumerated by membrane filtration followed by growth on Basic Fuchsin/sodium sulfite agar. Colony-forming units (CFUs) were counted within $48 \mathrm{~h}$ of incubation at $37^{\circ} \mathrm{C}$. The spread plate method was used to determine HPC and TBC. For HPC, bacteria were grown on R2A agar at $25^{\circ} \mathrm{C}$ for $7 \mathrm{~d}$; for TBC, bacteria were grown on nutrient agar at $37^{\circ} \mathrm{C}$ for $48 \mathrm{~h}$. The detection limits between the analytical methods are different. We defined the absence of microorganisms as $<30 \mathrm{CFU} / \mathrm{ml}$ for the spread plate method and $<10 \mathrm{CFU} / 100 \mathrm{ml}$ for the membrane filtration method.

\subsection{UV disinfection and photoreactivation}

UV irradiation experiments were conducted using standard collimated beam tests. A low-pressure lamp (11 W; Beijing Lighting Research Institute, China) with emission primarily at $253.7 \mathrm{~nm}$ was mounted horizontally over a collimating tube. A Petri dish (diameter, $60 \mathrm{~mm}$ ) containing $20 \mathrm{~mL}$ of wastewater was placed, with stirring, under the collimated beam. At the center of the solution surface, the incident intensity was approximately $0.125 \mathrm{~mW} / \mathrm{cm}^{2}$. The UV dose was calculated as described by Bolton and Karl (2003).

The photoreactivation experiments were performed under three fluorescent lamps, with the light intensity of

Table 1 - Water quality characteristics of wastewater samples used in this study.

\begin{tabular}{lll} 
Parameter & W1 & W2 \\
\hline Abs $_{254} \mathrm{~nm}$ & 0.1035 & 0.2434 \\
$\mathrm{pH}$ & 7.74 & 8.62 \\
$\mathrm{DOC}(\mathrm{mg} / \mathrm{L})$ & 5.243 & 9.911 \\
$\mathrm{DON}(\mathrm{mg} / \mathrm{L})$ & 2.903 & 1.393 \\
$\mathrm{NH}_{3}-\mathrm{N}(\mathrm{mg} / \mathrm{L})$ & 0.203 & 0.298 \\
Turbidity $(\mathrm{NTU})$ & 0.2 & 1.6 \\
TSS $(\mathrm{mg} / \mathrm{L})$ & 0.56 & 2.71 \\
VSS $(\mathrm{mg} / \mathrm{L})$ & 0.23 & 0.88 \\
$\mathrm{HPC}(\mathrm{CFU} / \mathrm{ml})$ & $1.27 \times 10^{5}$ & $3.13 \times 10^{4}$ \\
TBC $(\mathrm{CFU} / \mathrm{ml})$ & $1.02 \times 10^{4}$ & $2.91 \times 10^{3}$ \\
TC $(\mathrm{CFU} / 100 \mathrm{ml})$ & $9.01 \times 10^{3}$ & $4.37 \times 10^{4}$ \\
\hline
\end{tabular}


$0.066 \mathrm{~mW} / \mathrm{cm}^{2}$ at $360 \mathrm{~nm}$. The percentage of photoreactivation was computed as follows (Lindenauer and Darby, 1994):

Percentage photoreactivation (\%)

$$
=\frac{\text { No. of cells photoreactivated }}{\text { No. of cells inactivated by UV }} \times 100 \%
$$

\subsection{Chlorine disinfection}

A $9 \%$ sodium hypochlorite solution was diluted in ultrapure water to prepare a stock solution. The chlorine concentration was measured using the N,N-diethyl-p-phenylenediamine colorimetric method, according to the standard method of Water and Wastewater Monitoring of China. Chlorine residuals in the bacteria enumeration samples were immediately neutralized with $10 \%$ sodium thiosulfate. To ensure sterility, all materials used in the experiments were autoclaved at $121^{\circ} \mathrm{C}$ for $25 \mathrm{~min}$. All experiments were performed at room temperature $\left(25 \pm 2{ }^{\circ} \mathrm{C}\right)$ and were repeated three times.

\subsection{Disinfection by-product formation and analysis}

The concentration of trihalomethanes (THMs) was determined using a gas chromatograph (6890 N; Agilent) with an
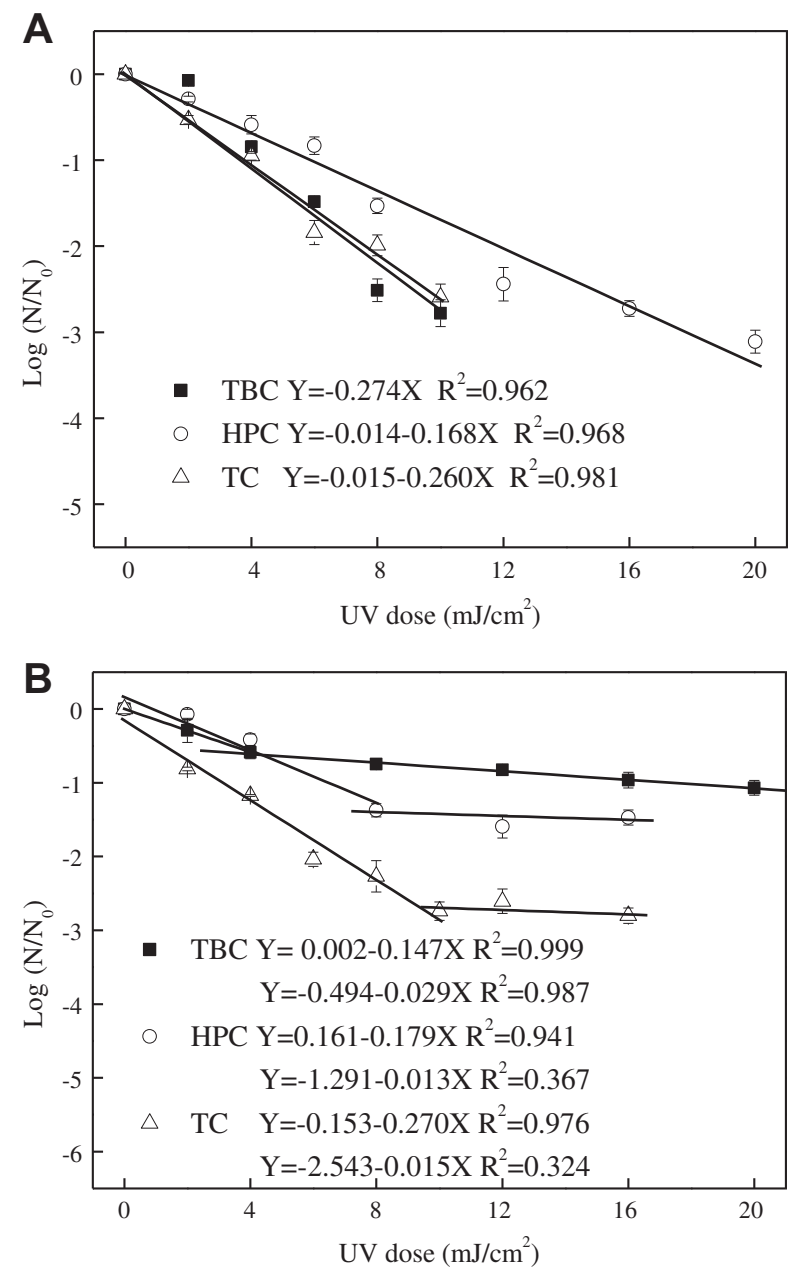

Fig. 1 - Kinetics of the tested bacteria in W1 (A) and W2 (B) response to UV irradiation. electron capture detector and a fused silica capillary column (HP-5, $30 \mathrm{~m}, 320 \mu \mathrm{m} \times 0.25 \mu \mathrm{m}$ ), according to USEPA method 551.1. Chlorine in the samples was quenched with sodium sulfite, and THMs were measured using the following temperature program: hold at $35^{\circ} \mathrm{C}$ for $4 \mathrm{~min}$ and ramp to $60^{\circ} \mathrm{C}$ at $10^{\circ} \mathrm{C} / \mathrm{min}$.

\section{Results and discussion}

\subsection{UV disinfection and photoreactivation in wastewater}

Fig. 1 shows the inactivation kinetics of HPC, TBC, and TC in W1 and W2 wastewaters with UV irradiation. In W1 wastewater, the log survival of the three bacteria and the UV dose used for inactivation showed a strong first-order relationship $\left(r^{2}>0.960\right)$. Among the three bacteria, TBC was the most sensitive to UV irradiation $\left(k=0.274 \mathrm{~cm}^{2} \mathrm{~m} \mathrm{~W}^{-1} \mathrm{~s}^{-1}\right)$, followed by TC $\left(k=0.260 \mathrm{~cm}^{2} \mathrm{~m} \mathrm{~W}^{-1} \mathrm{~s}^{-1}\right)$ and HPC $\left(k=0.168 \mathrm{~cm}^{2} \mathrm{~m} \mathrm{~W}^{-1} \mathrm{~s}^{-1}\right)$. Before disinfection, the concentrations for TBC, HPC, and TC in W1 wastewater were 3.98, 4.86, and $4.29 \log$ units, respectively. Treatment with UV at 8, 20 , and $10 \mathrm{~mJ} / \mathrm{cm}^{2}$, respectively, reduced these values nearly to the detection limits. In contrast, in W2 wastewater, UV inactivation of the three bacterial indicators followed first-order kinetics until approximately $10 \mathrm{~mJ} / \mathrm{cm}^{2}$, after which significant tailing occurred with slower bacteria inactivation.

The UV inactivation kinetics of pathogenic bacteria in filtered W1 and W2 wastewaters have been reported to be the same as those in phosphate-buffered saline (Wang et al., 2011), indicating that dissolved matter in W2 wastewater had no impact on the UV inactivation of pathogenic bacteria. The turbidity and total suspended solids were 1.6 NTU and $2.71 \mathrm{mg} / \mathrm{L}$, respectively, in W2 wastewater, compared with $0.2 \mathrm{NTU}$ and $0.56 \mathrm{mg} / \mathrm{L}$, respectively, in W1 wastewater. This suggests that particles might account for the decreased UV inactivation in W2 wastewater, as attached or embedded bacteria have shown increased resistance to UV inactivation (Winward et al., 2008). Cantwell and Hofmann (2008) reported that particles as small as $11 \mu \mathrm{m}$, which are naturally

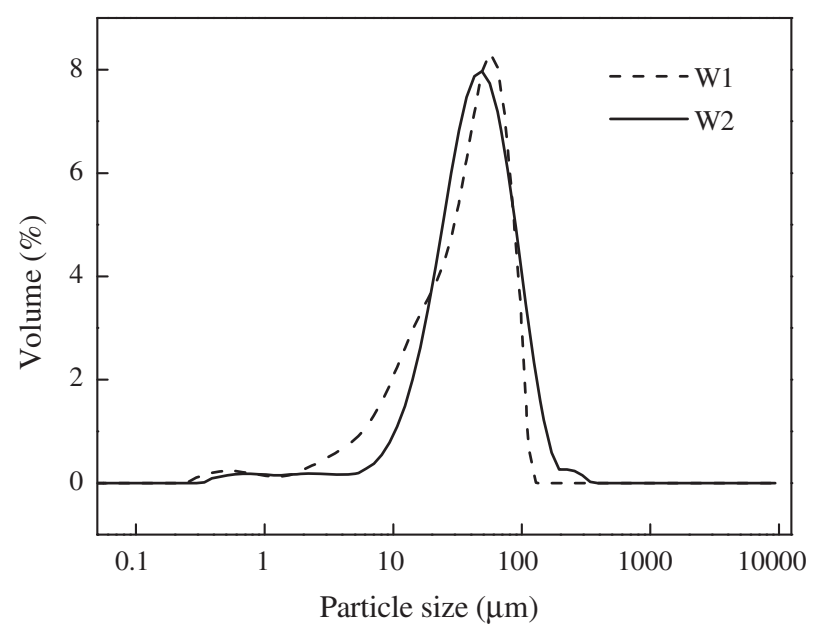

Fig. 2 - Particle size distributions of wastewater samples. 
found in surface water with low turbidity ( $<3$ NTU), can harbor indigenous coliform bacteria and offer protection from low-pressure UV light. The volume-weighted mean particle sizes were $52 \mu \mathrm{m}$ and $41 \mu \mathrm{m}$ and in W2 and W1 wastewater respectively (Fig. 2). The result indicated that the efficacy of UV disinfection of wastewaters was linked to both the size of the particles and the turbidity in wastewaters. However, the inactivation of the three bacteria in W2 wastewater still occurred with the increase of UV dose. TC and TBC were reduced to below the detection limits at UV doses of $20 \mathrm{~mJ} / \mathrm{cm}^{2}$ and $40 \mathrm{~mJ} / \mathrm{cm}^{2}$, respectively, whereas the HPC was $64 \mathrm{CFU} / \mathrm{ml}$, even at a UV dose of $160 \mathrm{~mJ} / \mathrm{cm}^{2}$ (Supplementary Material Fig. S1). These results suggest that most of the coliform bacteria were dispersed in the W2 wastewater, while some of the other bacteria were embedded within particulate matter, where they were shielded from UV light.

Fig. 3 illustrates the photoreactivation of bacteria after exposure to different UV doses. After UV treatment with $4 \mathrm{~mJ} /$ $\mathrm{cm}^{2}, 28 \%$ of the TBC and $50 \%$ of the HPC bacteria in W1 wastewater were reactivated under a fluorescent lamp; the respective photorepair rates were $80 \%$ and $53 \%$ in W2 wastewater. Other UV doses showed a similar trend, with lower photoreactivation percentages in W1 wastewater compared
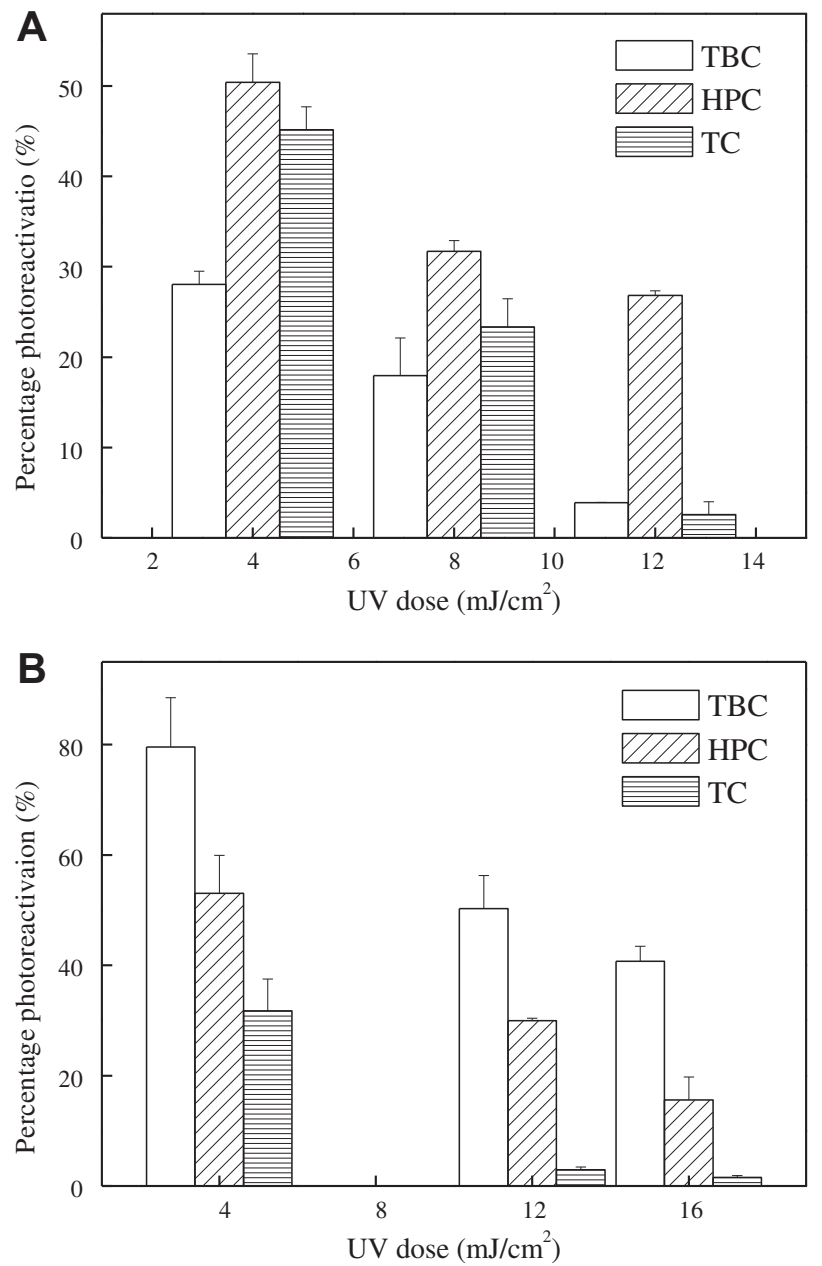

Fig. 3 - Effect of UV dose $\left(\mathrm{mJ} / \mathrm{cm}^{2}\right)$ on photoreactivation of the tested bacteria in $\mathrm{W} 1$ (A) and W2 (B). with W2 wastewater. In addition, bacteria embedded in particles in the W2 wastewater might have been protected from UV-induced bacterial damage and released into solution after UV disinfection. The photoreactivation rate decreased in all three bacterial indicators as the UV dose increased, suggesting that higher UV doses should be applied to completely eliminate photoreactivation.

\subsection{Wastewater disinfection with chlorine}

The effect of the chlorine dose on the inactivation of bacteria in W1 and W2 wastewaters is shown in Figs. 4 and 5 respectively. At the contact time of $30 \mathrm{~min}$, which is standard in wastewater treatment plants, a chlorine concentration of $3.5 \mathrm{mg} / \mathrm{L}$ reduced the TBC to an undetectable level in W1 wastewater, whereas more than $5.5 \mathrm{mg} / \mathrm{L}$ chlorine was required to decrease the HPC to an undetectable level. In W2 wastewater, both the TBC and HPC were reduced to undetectable levels by chlorine concentrations of 4 and $4.5 \mathrm{mg} / \mathrm{L}$, respectively. Thus, suspended solids did not inhibit bacterial inactivation by chlorine, implying that chlorine is capable of
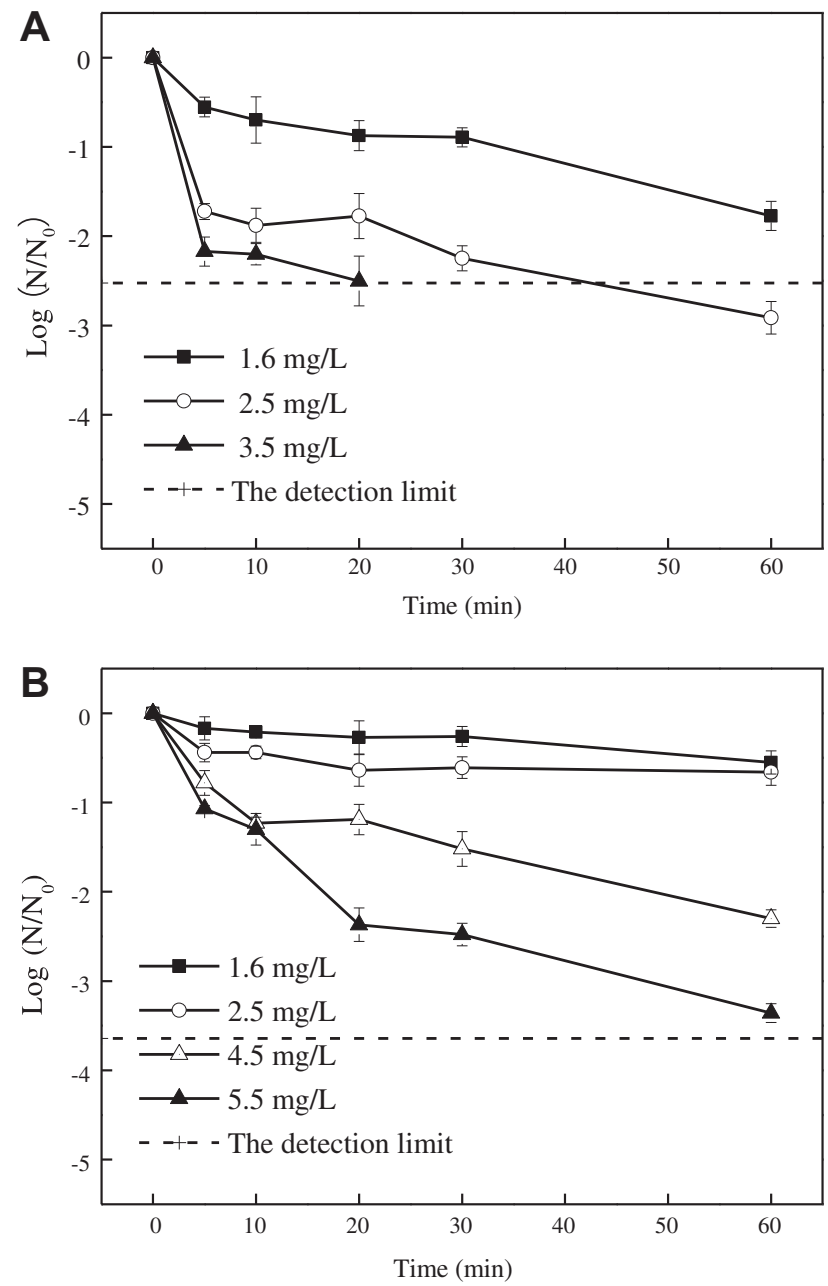

Fig. 4 - Inactivation of bacteria indicators by chlorine in W1. The symbols are means of three independent experiments and the error bars indicate standard deviation. (A) TBC (B) HPC. 

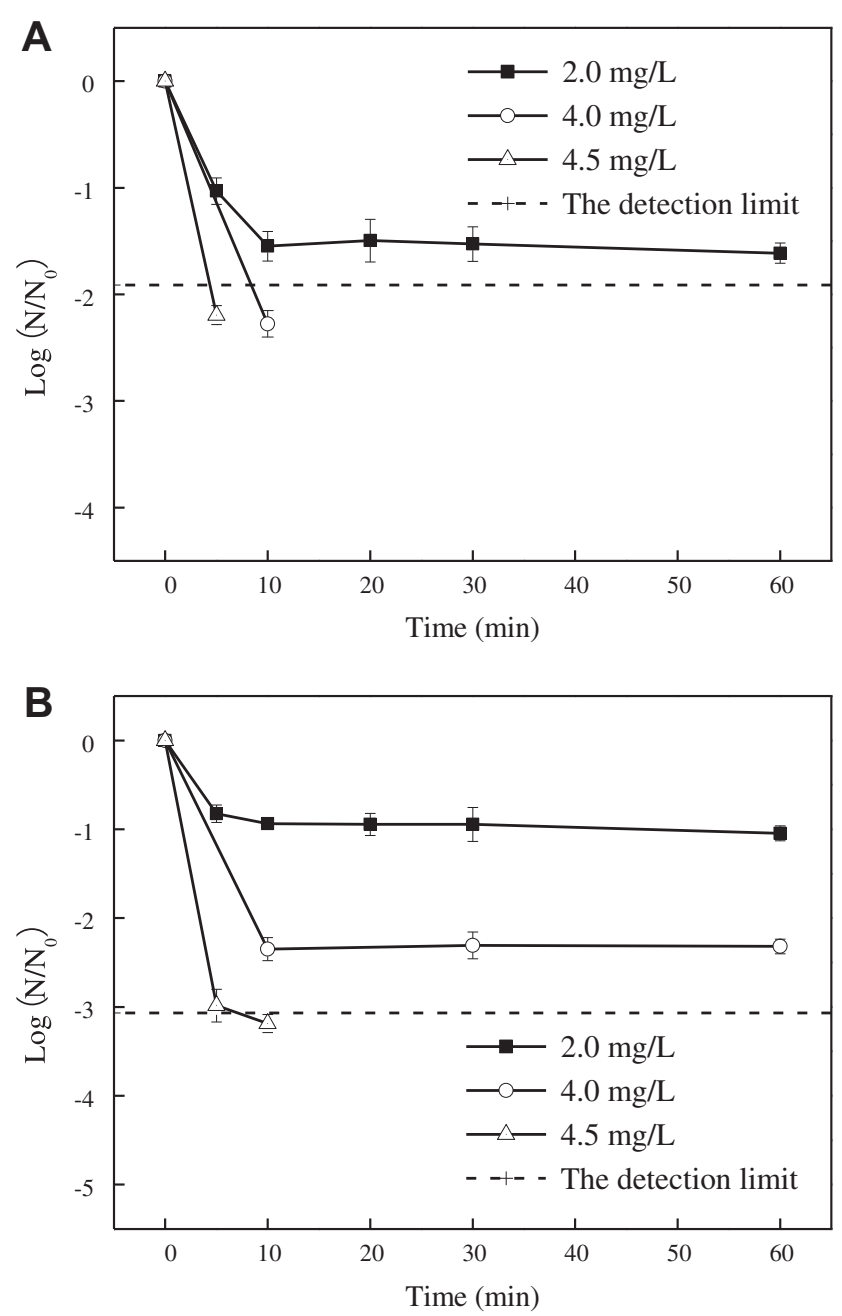

Fig. 5 - Inactivation of bacteria indicators by chlorine in W2. The symbols are means of three independent experiments and the error bars indicate standard deviation. (A) TBC and (B) HPC.

penetrating macroporous network of pathways within wastewater particles (Dietrich et al., 2003).

The free and total chlorine were monitored by standard methods for the examination of water and wastewater (APHA, 1998) during the disinfection. As shown in Fig. 6, in W1 wastewater, the free chlorine was promptly consumed within initial $1.5 \mathrm{~min}$, giving residual free chlorine concentrations of $0.14,0.21,0.35,0.48$, and $0.67 \mathrm{mg} / \mathrm{L}$, and total chlorine concentrations of $1.13,1.79,2.12,2.41$, and $2.88 \mathrm{mg} / \mathrm{L}$ for initial chlorine doses of $1.60,2.50,3.50,4.50$, and $5.50 \mathrm{mg} / \mathrm{L}$, respectively. Obviously, the combined chlorine was predominant in the total chlorine. Moreover, total chlorine in W1 wastewater did not decay rapidly within the reaction time. After $30 \mathrm{~min}$ of contact, the total residual chlorine concentrations were higher than the standard for reclaimed water $(1 \mathrm{mg} / \mathrm{L})$ in different initial chlorine doses. Since the $\mathrm{NH}_{3}-\mathrm{N}$ and dissolved organic nitrogen concentration were $0.203 \mathrm{mg} / \mathrm{L}$ and $2.903 \mathrm{mg} / \mathrm{L}$ in W1 wastewater respectively, the amount of inorganic chloramines was smaller, the major portion was organic chloramines, which was produced by the reaction of
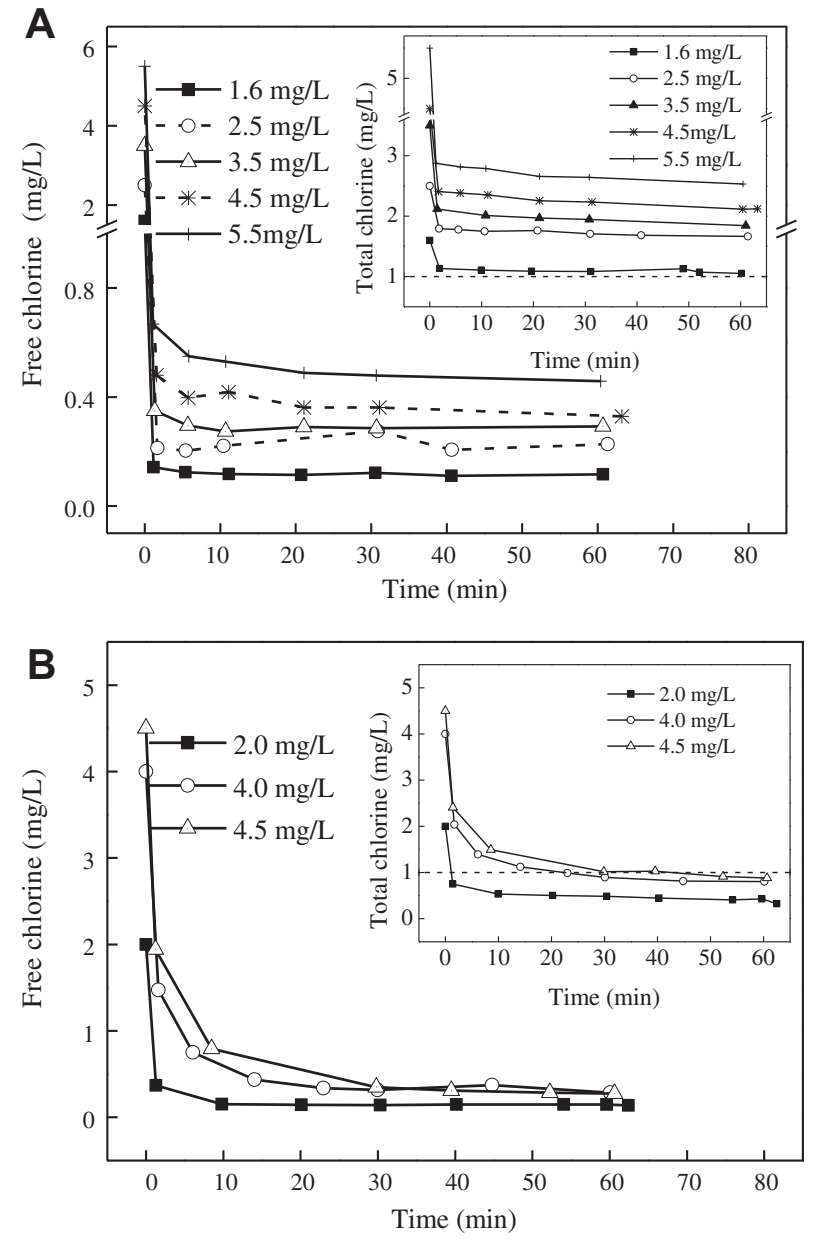

Fig. 6 - Decay of free chlorine and total chlorine as a function of disinfection time in W1 (A) and W2 (B).

chlorine with organic N-containing compounds in the wastewater (Shang and Blatchley, 2001). The lower total chlorine depletion was mainly contributed to the organic chloramines. In W2 wastewater, the residual free chlorine were $0.37,1.47$ and $1.94 \mathrm{mg} / \mathrm{L}$, and the total chlorine were 0.75 , 2.04 and $2.41 \mathrm{mg} / \mathrm{L}$ at the reaction time of $1.5 \mathrm{~min}$ for initial chlorine doses of $2.00,4.00,4.50 \mathrm{mg} / \mathrm{L}$, respectively. The free chlorine was predominant in the total chlorine and total chlorine decayed more rapidly in W2 wastewater than in W1 wastewater. At the contact time $30 \mathrm{~min}$, the total chlorine concentration were much more than $1 \mathrm{mg} / \mathrm{L}$ in W1 for all the tested initial chlorine doses, while those ones were near to $1 \mathrm{mg} / \mathrm{L}$ in W2 just for more than $4 \mathrm{mg} / \mathrm{L}$ initial chlorine dose. Since in W2 wastewater, the $\mathrm{NH}_{3}-\mathrm{N}$ and dissolved organic nitrogen concentration were $0.298 \mathrm{mg} / \mathrm{L}$ and $1.393 \mathrm{mg} / \mathrm{L}$, less than those ones in W1. Correspondingly, the combined chlorine was formed less than that one in W1, which was one reason for higher total chlorine depletion. On the other hand, the dissolved organic carbon (DOC) concentration was higher in W2 wastewater $(9.911 \mathrm{mg} / \mathrm{L})$ than that in W1 wastewater $(5.243 \mathrm{mg} / \mathrm{L})$, and this might have contributed to the faster decay rate of total chlorine in W2 wastewater. No significant difference in total chlorine consumption was observed between raw W2 and filtered W2 wastewater, indicating that 

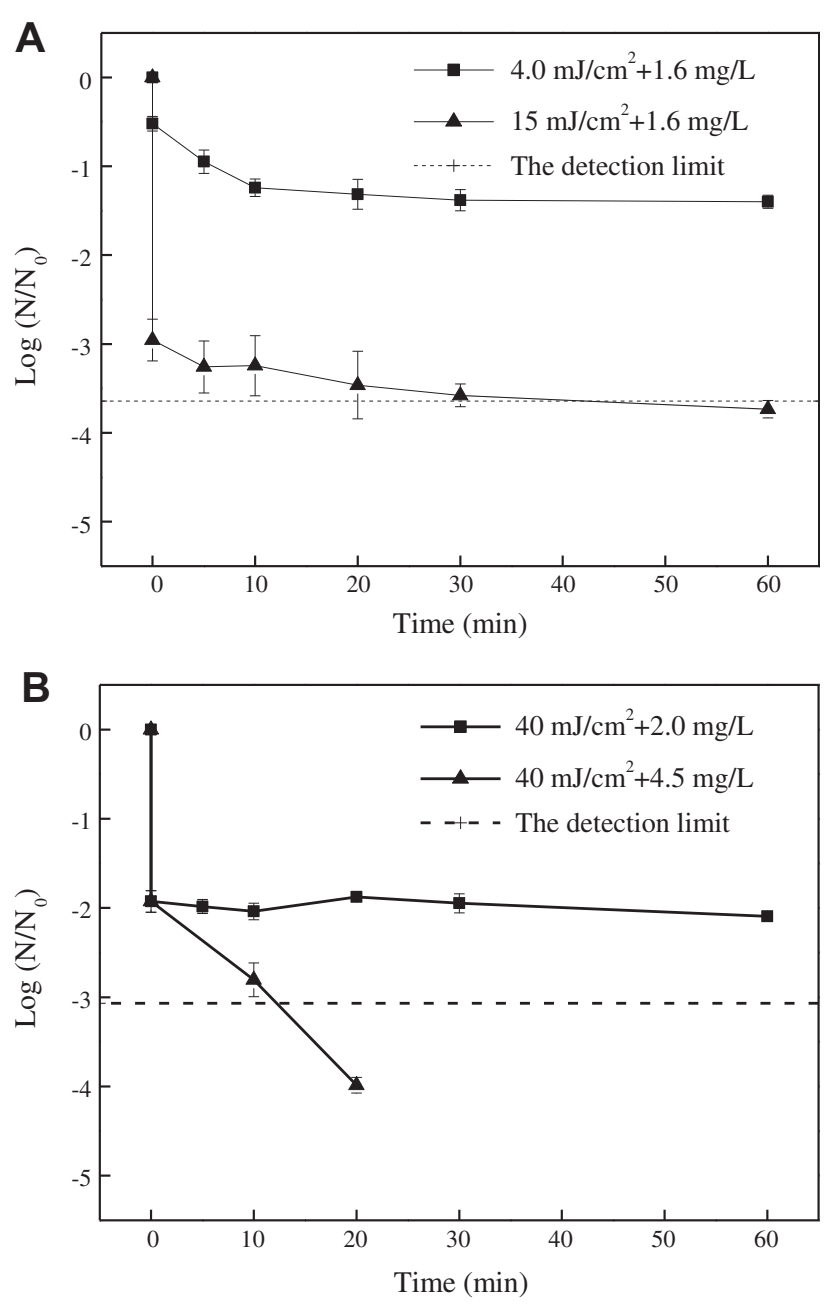

Fig. 7 - Inactivation of HPC by sequential $\mathrm{UV}$ and $\mathrm{Cl}_{2}$. The symbols are means of three independent experiments and the error bars indicate standard deviation. (A) W1, (B) W2.

suspended particles in W2 wastewater did not affect the decay of chlorine (Supplementary Material Fig. S2).

\subsection{Combined UV and chlorine treatment}

Our results revealed deficiencies in the use of UV irradiation alone or chlorine alone for disinfection, including incomplete inactivation of bacteria, photoreactivation of bacteria, and increased requirements for chlorine. To address these limitations, we investigated the combined use of UV and chlorine. As shown in Fig. 7A and Supplementary Material Fig. S3, UV irradiation of $15 \mathrm{~mJ} / \mathrm{cm}^{2}$ almost completely reduced the TBC and HPC, by 4.01 and 5.10 log units, respectively, in W1 wastewater. A subsequent $30 \mathrm{~min}$ treatment with $1.6 \mathrm{mg} / \mathrm{L}$ chlorine further reduced the TBC and HPC to below the detection limits. Moreover, the free chlorine and total chlorine decay rates were almost the same as those with chlorine disinfection alone (Supplementary Material Fig. S4), with a total residual chlorine above the standard value of $1 \mathrm{mg} / \mathrm{L}$. These results verified that the synergistic effect of UV and chlorine increased the inactivation rate of bacteria and lowered the required chlorine dose for $\mathrm{W} 1$ wastewater disinfection. A synergistic bactericidal effect of UV and chlorine also occurred in W2 wastewater. After UV treatment $\left(40 \mathrm{~mJ} / \mathrm{cm}^{2}\right)$ followed by chlorine treatment $(2.0 \mathrm{mg} / \mathrm{L})$, the TBC and HPC were reduced by 3.46 and $4.50 \log$ units, respectively, with no observable photoreactivation of bacteria. Treatment with $4.5 \mathrm{mg} / \mathrm{L}$ chlorine for $30 \mathrm{~min}$ produced even greater reductions in the TBC and HPC, to below the detection limits, and gave total residual chlorine of $1.02 \mathrm{mg} / \mathrm{L}$, just above the standard value for reclaimed water. Thus, UV disinfection lowered the required chlorine dose in $\mathrm{W} 2$ wastewater.

\subsection{DBP formation during different disinfection protocols}

The formation of total trihalomethanes (TTHMs) was determined after different disinfection protocols. As shown in Table 2 , the concentration of TTHMs in W1 wastewater was $16.0 \mu \mathrm{g} / \mathrm{L}$ before disinfection, which resulted from the process of prechlorination, and decreased to $14.9 \mu \mathrm{g} / \mathrm{L}$ after irradiation by $15 \mathrm{~mJ} / \mathrm{cm}^{2}$ of UV alone. With chlorine treatment alone at 3.5 and $4.5 \mathrm{mg} / \mathrm{L}$, the TTHM concentrations were 25.0 and $27.2 \mu \mathrm{g} /$ $\mathrm{L}$, respectively. However, when UV treatment at $15 \mathrm{~mJ} / \mathrm{cm}^{2}$ preceded treatment with $1.6 \mathrm{mg} / \mathrm{L}$ chlorine, the TTHM concentration was $19.7 \mu \mathrm{g} / \mathrm{L}$, indicating that UV disinfection lowered the required chlorine dose and decreased TTHM formation in W1 wastewater. In W2 wastewater, the TTHM concentration was $8.6 \mu \mathrm{g} / \mathrm{L}$ before disinfection. No TTHMs were detected after exposure to UV of $40 \mathrm{~mJ} / \mathrm{cm}^{2}$. The TTHM concentration after treatment with $4.5 \mathrm{mg} / \mathrm{L}$ chlorine alone was $65.7 \mu \mathrm{g} / \mathrm{L}$, and the concentration decreased to $60.2 \mu \mathrm{g} / \mathrm{L}$ when the same chlorine treatment was preceded by UV treatment at $40 \mathrm{~mJ} / \mathrm{cm}^{2}$. UV irradiation slightly decreased the TTHM formation in W2 wastewater, possibly due in part to UV-induced structural changes in DOM compounds. Various studies had revealed that UV irradiation at high UV doses could alter organic matter in water by reducing TOC content, color and molecular size (Corin et al., 1996). Magnuson et al. (2002) found that UV irradiation resulted in the changes of mass spectra of NOM at the range of UV dose from 20 to $140 \mathrm{~mJ} / \mathrm{cm}^{2}$. These changes might alter the reactivity of NOM with chlorine

Table 2 - Disinfection by-product yields $(\mu \mathrm{g} / \mathrm{L})$ for experimental conditions.

\begin{tabular}{lllllllllc} 
Water source & \multicolumn{1}{c}{ W1 } & \multicolumn{3}{c}{ W2 } \\
\hline $\mathrm{UV}\left(\mathrm{m} / \mathrm{cm}^{2}\right)$ & - & 15 & 15 & - & - & - & - & 40 & 40 \\
$\mathrm{Cl}(\mathrm{mg} / \mathrm{L}, 1 \mathrm{~h})$ & - & - & 1.6 & 1.6 & 3.5 & 4.5 & - & - & 4.5 \\
$\mathrm{TTHMs}(\mu \mathrm{L} / \mathrm{L})$ & 16.0 & 14.9 & 19.7 & 19.2 & 25.0 & 27.2 & 8.6 & - & 60.2 \\
\hline
\end{tabular}


and then effect the formation of DPBs in subsequent chlorination, which would be studied in detail in another work.

\section{Conclusions}

UV irradiation alone did not effectively disinfect W2 wastewater because of its higher particle content, and chlorine alone exhibited low disinfection efficiency in W1 wastewater owing to the increased formation of inorganic and organic chloramines. However, sequential disinfection with UV and chlorine worked synergistically to effectively reduce the HPC, TBC, and TC and to inhibit TTHM formation in both W1 and W2 wastewater. The complete inactivation of HPC in W1 wastewater was accomplished by treatment with $15 \mathrm{~mJ} / \mathrm{cm}^{2}$ UV followed by $1.6 \mathrm{mg} / \mathrm{L}$ chlorine. This result could not be achieved with chlorine treatment alone, even with $5.5 \mathrm{mg} / \mathrm{L}$ chlorine. In W2 wastewater, TBC were completely inactivated by sequential application of $40 \mathrm{~mJ} / \mathrm{cm}^{2} \mathrm{UV}$ and $2 \mathrm{mg} / \mathrm{L}$ chlorine. To produce this level of inactivation with chlorine treatment alone, a chlorine dose of $4 \mathrm{mg} / \mathrm{L}$ was required. In W1 wastewater, initial treatment with UV irradiation allowed the chlorine dose to be lowered to $1.6 \mathrm{mg} / \mathrm{L}$, which enabled the total residual chlorine to be maintained at $1 \mathrm{mg} / \mathrm{L}$. However, UV irradiation did not decrease the required chlorine dose of $4.5 \mathrm{mg} / \mathrm{L}$ in W2 wastewater because of the higher consumption of chlorine in W2 wastewater. In both wastewaters, prior UV irradiation inhibited TTHM formation during chlorine treatment, reducing the TTHM concentration by $7.5 \mu \mathrm{g} / \mathrm{L}$ in W1 wastewater and by $5.5 \mu \mathrm{g} / \mathrm{L}$ in W2 wastewater.

\section{Acknowledgments}

This work was supported by the National Major Project of Science \& Technology Ministry of China (No. 2008ZX07314003, 2009ZX07424-003) and the National 863 Project of China (No. 2008AA062501, 2008AA06A414).

\section{Appendix. Supplementary data}

Supplementary data related to this article can be found online at doi:10.1016/j.watres.2011.12.027.

\section{REFEREN CES}

Adin, A., Katzhendler, J., Alkaslassy, D., Rav-Acha, C., 1991. Trihalomethane formation in chlorinated drinking water: a kinetic model. Water Research 25 (7), 797-805.

APHA, AWWA, and WEF, 1998. Standard Methods for the Examination of Water and Wastewater, twentieth ed. American Public Health Association, Washington, DC.

Ballester, N.A., Malley, J.P., 2004. Sequential disinfection of adenovirus type 2 with UV-chlorine-chloramine. Journal of the American Water Works Association 96 (10), 97-103.

Bolton, J.R., Karl, G.L., 2003. Standardization of methods for fluence (UV dose) determination in bench-scale UV experiments. Journal of Environmental Engineering 129 (3), 209-215.

Cantwell, R.E., Hofmann, R., 2008. Inactivation of indigenous Coliform bacteria in unfiltered surface water by ultraviolet light. Water Research 42 (10-11), 2729-2735.

Corin, N., Backlund, P., Kulovaara, M., 1996. Degradation products formed during UV-irradiation of humic waters. Chemosphere 33 (2), 245-255.

Cotton, C.A., Owen, D.M., Cline, G.C., Brodeur, T.P., 2001. UV disinfection costs for inactivating Cryptosporidium. Journal of the American Water Works Association 93 (6), 82-94.

Dietrich, J.P., Basagaoglu, H., Loge, F.J., Ginn, T.R., 2003. Preliminary assessment of transport processes influencing the penetration of chlorine into wastewater particles and the subsequent inactivation of particle-associated organisms. Water Research 37 (1), 139-149.

Fawell, J., Robinson, D., Bull, R., Birnbaum, L., Boorman, G., Butterworth, B., Daniel, P., Gorchev, H.G., Hauchman, F., Julkunen, P., Klaassen, C., Krasner, S., Zavaleta, J.O., Reif, J., Tardiff, R., 1997. Disinfection by-products in drinking water: critical issues in health effects research. Environmental Health Perspectives 105, 108-109.

Hassen, A., Mahrouk, M., Ouzari, H., Cherif, M., Boudabous, A., Damelincourt, J.J., 2000. UV disinfection of treated wastewater in a large-scale pilot plant and inactivation of selected bacteria in a laboratory UV device. Bioresource Technology 74 (2), 141-150.

Korich, D.G., Mead, J.R., Madore, M.S., Sinclair, N.A., Sterling, C.R., 1990. Effects of ozone, chlorine dioxide, chlorine, and monochloramine on Cryptosporidium paruum oocyst viability. Applied and Environmental Microbiology 56 (5), 1423-1428.

Liberti, L., Notarnicola, M., Petruzzelli, D., 2003. Advanced treatment for municipal wastewater reuse in agriculture. UV disinfection: parasite removal and by-product formation. Desalination 152 (1-3), 315-324.

Lindenauer, K.G., Darby, J.L., 1994. Ultraviolet disinfection of wastewater: effect of dose on subsequent photoreactivation. Water Research 28 (4), 805-817.

Liu, W., Andrews, S.A., Bolton, J.R., Linden, K.G., Sharpless, C.M., Stefan, M., 2002. Comparison of DBP formation from different UV technologies at bench scale. Water Science and Technology: Water Supply 2 (5-6), 515-521.

Mackenzie, W.R., Hoxie, N.J., Procter, M.E., Gradus, M.S., Blair, K.A., Peterson, D.E., Kazmerczak, J.J., Addiss, D.G., Fox, K.R., Rose, J.B., Davis, J.P., 1994. A massive outbreak in Milwaukee of Cryptosporidium infection transmitted through the public water supply. The New England Journal of Medicine 331, 161-167.

Magnuson, M.L., Kelty, C.A., Sharpless, C.M., Linden, K.G., Fromme, W., Metz, D.H., Kashinkunti, R., 2002. Effect of UV irradiation on organic matter extracted from treated Ohio River water studied through the use of electrospray mass spectrometry. Environmental Science and Technology 36 (23), 5252-5260.

Montemayor, M., Costan, A., Lucena, F., Jofre, J., Muñoz, J., Dalmau, E., Mujeriego, R., Sala, L., 2008. The combined performance of UV light and chlorine during reclaimed water disinfection. Water Science Technology 57 (6), 935-940.

Oguma, K., Katayama, H., Ohgaki, S., 2004. Photoreactivation of Legionella pneumophila after inactivation by low- or mediumpressure ultraviolet lamp. Water Research 38 (11), 2757-2763.

Rand, J.L., Hofmann, R., Alam, M.Z.B., Chauret, C., Cantwell, R., Andrews, R.C., Gagnon, G.A., 2007. A field study evaluation for mitigating biofouling with chlorine dioxide or chlorine integrated with UV disinfection. Water Research 41 (9), 1939-1948. 
Shang, C., Blatchley, E.R., 2001. Chlorination of pure bacterial cultures in aqueous solution. Water Research 35 (1), 244-254.

Shang, C., Cheung, L.-M., Liu, W., 2007. MS2 coliphage inactivation with UV irradiation and free chlorine/ monochloramine. Environmental Engineering Science 24 (9), 1321-1332.
Wang, X., Hu, C., Hu, X., Wei, D., 2011. Sequential use of ultraviolet light and chlorine for reclaimed water disinfection. Journal of Environmental Sciences 23 (10), 1605-1610.

Winward, G.P., Avery, L.M., Stephenson, T., Jefferson, B., 2008. Ultraviolet (UV) disinfetion of grey water: particle size effects. Environmental technology 29 (2), 235-244. 